\title{
PELATIHAN PENYUSUNAN LEMBAR KEGIATAN SISWA BERBASIS KURIKULUM 2013 BAGI GURU-GURU DI YAYASAN KEMALA BHAYANGKARI
}

\author{
Oleh \\ Wisanti, Muslimin Ibrahim, Herlina Fitrihidajati, dan Eva Kristinawati Putri")
}

\begin{abstract}
Abstrak
Tujuan kegiatan pengabdian kepada masyarakat ini adalah (1) Melatihkan penyusunan LKS berbasis Kurikulum 2013 bagi guru-guru Yayasan Kemala Bhayangkari Surabaya dan (2) Pendampingan guru-guru Yayasan kemala Bhayangkari Surabaya selama pembuatan LKS berbasis Kurikulum 2013. Kegiatan PKM dikemas dalam bentuk workshop dan dilanjutkan kegiatan review LKS yang telah disusun oleh peserta workshop. Khalayak sasaran PKM adalah para guru Yayasan Kemala Bhayangkari Surabaya. Kegiatan dilaksanakan satu hari untuk workshop, 2 minggu untuk penyusunan LKS dan 1 minggu untuk review LKS. Instrumen yang digunakan dalam kegiatan PKM ini berupa angket respons peserta workshop, lembar telaah LKS serta sumber pustaka berupa contoh LKS berbasis saintifik. Kegiatan workshop dilaksanakan hari sabtu, tanggal 13 September 2014 Kegiatan ini diikuti oleh 20 guru dari Yayasan kemala Bhayangkari Surabaya meliputi guru SD, SMP dan SMA. Kegiatan workshop berjalan dengan tertib dan menghasilkan produk berupa desain awal LKS yang akan disusun. Namun, untuk LKS yang disusun oleh tiap kelompok tidak tepat waktu dikirimkan ke tim PKM, hanya ada 7 LKS yang telah diterima tim PKM. Setelah ditelaah oleh tim PKM, naskah LKS yang disusun peserta sudah memenuhi kriteria kelayakan LKS yang cukup baik. Adpun rata-rata respons positif peserta terhadap pelaksanaan workshop Penyusunan LKS berbasis Kurikulum 2013 sebesar $96.67 \%$.
\end{abstract}

Kata kunci: LKS, Kurikulum 2013, Guru Bhayangkari

\begin{abstract}
The aims of this study are (1) to train teachers in Kemala Bhayangkari Foundation to conduct student worksheet based on Curriculum 2013 and (2) to accompany teachers in Kemala Bhayangkari Foundation during the construction process of student worksheet based on Curriculum 2013. This study was conducted in a workshop activity and review of student worksheets which were produced by participants. Participants were teachers of Kemala Bhayangkari Foundation. This workshop was conducted in a day, two weeks for the construction process of student worksheet and a week for review of student worksheet which was produced by participants. The instruments used were questionnaire for participant responses, questionnaire for student sheet review and references such as scientific student worksheet. Workshop was held on Saturday, 13 September 2014. There were 20 teachers of Kemala Bhayangkari Foundation as participants involving elementary school, junior high school and senior high school teachers. The workshop runs with orderly and produced the preliminary design of student worksheets that will be compiled. However, for worksheets prepared by each group were not timely delivered to the team of researcher, there were only seven worksheets that have been received by the team of researcher. Once reviewed by the team of researcher, student worksheet produced have met the eligibility criteria were pretty good. The average positive response of participants to the workshop reached by $96.67 \%$.
\end{abstract}

Keywords: Student worksheet, Curriculum 2013, teachers, Kemala Bhayangkari Foundation

*) Dosen di Jurusan Biologi Fakultas MIPA, Unesa 


\section{PENDAHULUAN}

Implementasi Kurikulum 2013 yang dilakukan oleh pemerintah pada dasarnya merupakan suatu upaya untuk meningkatkan kualitas Pendidikan dalam rangka menghasilkan lulusan yang lebih berkualitas. Esensi perubahan ialah ditetapkannya pendidikan karakter dan pembelajaran yang berbasis 5M (Menanya, Mengamati, Mengumpulkan data, Mengasosiasikan, dan Mengkomunikasikan) atau berbasis Saintifik (Nuh, 2013).

Tahap awal yang telah dilakukan oleh Pemerintah adalah penerapan di beberapa sekolah yang termasuk pilot project. Langkah ini telah dilakukan di kota Surabaya. Pemberlakuan penerapan Kurikulum 2013 di Sekolah telah dimulai pada semester gasal tahun ajaran 2013/2014 yang lalu. Kelemahannya adalah tidak semua sekolah menjadi sampel uji coba sebagai contoh salah satunya adalah SMA Kemala Bhayangkari 1 Surabaya yang merupakan sekolah swasta.

Sekolah Menengah Atas Kemala Bhayangkari 1 Surabaya merupakan salah satu sekolah yang berlokasi di jalan Achmad Yani Surabaya yang berlokasi berdekatan dengan UNESA dengan jarak kurang lebih $2 \mathrm{~km}$ dan merupakan sekolah mitra dari UNESA. Dari hasil diskusi diperoleh informasi bahwa sekolah ini berupaya untuk menerapkan Kurikulum 2013 tetapi masih menghadapi beberapa kendala antara lain pemahaman dan penerapan pendekatan Saintifik dalam proses pembelajaran serta keterbatasan nara sumber. Selain itu, sekolah sangat menginginkan suatu modul yang dimiliki oleh guru-gurunya. Salah satu bentuk modul dapat berupa Lembar Kegiatan Siswa (LKS) yang dapat digunakan untuk menunjang proses pembelajaran.

LKS pada dasarnya merupakan panduan terstruktur bagi siswa dalam melakukan kegiatan pembelajaran. Mengingat Kurikulum 2013 berbasis saintifik maka LKS yang disusun harus berbasis saintifik pula sehingga kegiatan yang dilakukan merupakan ajang latihan bagi siswa untuk menerapkan keterampilan saintifik antara lain berupa keterampilan bertanya, menjawab rumusan masalah dan melakukan pengamatan eksperimen atau eksplorasi dalam referensi, menalar, dan mengkomunikasikannya.

Permasalahan tersebut sesuai dengan temuan di lapangan saat tim PKM melakukan pendampingan Implementasi Kurikulum 2013 oleh Direktorat PSMP di beberapa Sekolah bagi guru IPA di wilayah Jatim dan Luar Jawa bahwa guru-guru masih kesulitan membuat perangkat berbasis saintifik. Selain itu tim PKM telah mengembangkan perangkat pembelajaran berbasis inkuiri atau saintifik dan hasilnya layak untuk diterapkan pada siswa (Fitrihidajati, dkk, 2009). Hasil pengembangan ini telah diuji cobakan pada siswa dan hasilnya baik serta direspon dengan baik oleh siswa (Fitrihidajati, dkk, 2010). Oleh karena itulah melalui usulan PKM tim dari jurusan Biologi FMIPA UNESA menawarkan solusi dalam mengatasi permasalahan di Sekolah Mitra, yaitu berupa pelatihan penyusunan LKS berbasis Saintifik untuk menunjang pelaksanaan Kurikulum 2013. 
Berdasarkan uraian di atas, maka tujuan kegiatan PKM ini adalah (1) Melatihkan penyusunan LKS berbasis Kurikulum 2013 bagi guru-guru Yayasan Kemala Bhayangkari Surabaya dan (2) Melakukan pendampingan guru-guru Yayasan kemala Bhayangkari Surabaya selama pembuatan LKS berbasis Kurikulum 2013.

\section{METODE PELAKSANAAN}

Kegiatan PKM ini dilakukan dengan menggunakan metode pelatihan. Pada kegiatan ini pendekatan yang digunakan mencakup baik secara teoritis maupun secara praktis. Khalayak sasaran yang dituju pada kegiatan ini adalah seluruh guru yayasan Kemala Bhayangkari Surabaya yaitu: guru SD, SMP dan SMA sebanyak 25 orang.

Sesuai dengan tujuan utama PKM tersebut dapat dijabarkan target pelatihan sebagai berikut,

\section{Pelatihan Penyusunan Lembar} Kegiatan Siswa Berbasis Kurikulum 2013 Bagi Guru-Guru Yayasan Kemala Bhayangkari Surabaya dapat terlaksana dengan baik jika memenuhi kriteria sebagai berikut, (a) Guru sebagai peserta pelatihan adalah guru SD, guru SMP dan guru SMA; (b) Jumlah peserta yang hadir paling sedikit 15 orang; (c) Semua tahapan pelatihan terlaksana sesuai dengan alokasi waktu yang ditentukan yaitu Penjelasan Pendekatan Saintifik dalam Kurikulum 2013 dan Syarat-syarat LKS yang baik disertai diskusi (60 menit), Telaah LKS oleh peserta dan presentasi (60 menit), Penentuan topik LKS (60 menit), dan Penyusunan desain LKS dan diskusi (240 menit).

2. Pelatihan penyusunan LKS oleh guru Yayasan Kemala

Bhayangkari ditargetkan menghasilkan naskah LKS yang sesuai dengan syarat-syarat LKS yang baik dan berbasis pendekatan saintifik yang menyangkut; identitas LKS, syarat teknis, kebahasaan, isi/konsep dan sikap ilmiah yang dilatihkan.

3. Respons guru terhadap pelaksanaan pelatihan penyusunan LKS ini dikatakan baik jika memenuhi kriteria $80 \%$ peserta memberikan respons positif (menjawab ya) untuk 12 pernyataan yang terkait aspek materi pelatihan, manfaat pelatihan, kompetensi tim PKM dan keterlaksanaan PKM.

\section{HASIL DAN PEMBAHASAN}

\section{Pelaksanaan PKM}

Kegiatan PKM dilaksanakan pada hari Sabtu, tanggal 13 September 2014. Acara PKM ini dibuka oleh Kepala Sekolah SMP Kemala Bhayangkari 1 Surabaya, yaitu bapak Agus Setijarno. Kegiatan ini diikuti oleh 20 guru dari Yayasan Kemala Bhayangkari Surabaya, dengan rincian sebagai berikut: 10 guru SD, 4 guru SMP dan 6 guru SMA.

Pelaksanaan kegiatan berjalan lancar dan diikuti oleh peserta dengan 
serius dan antusias. Berikut ini diuraikan tentang hasil setiap tahapan kegiatan PKM:

\section{a. Penjelasan Materi Pelatihan}

Materi pelatihan disampaikan oleh narasumber dari tim PKM yaitu materi Pengembangan LKS dalam kerangka Kurikulum 2013 dan syarat-syarat LKS yang baik.
b. Latihan Telaah LKS
Setelah kegiatan penyampaian dan penjelasan materi selesai,

pelaksanaan PKM dilanjutkan dengan latihan melakukan telaah LKS yang digunakan di sekolah. Peserta diminta untuk berkelompok, tiap kelompok terdiri 2 orang. Tiap kelompok berdikusi menelaah LKS yang disediakan tim PKM dengan menggunakan instrumen telaah. Hasil telaah LKS tiap kelompok dipresentasikan dan peserta lainnya diberi kesempatan untuk menanggapi, sehingga terjadi diskusi klasikal.

Tabel 1. Rekapitulasi Naskah LKS yang Ditelaah oleh guru-guru peserta pelatihan

\begin{tabular}{cll}
\hline Kelompok & \multicolumn{1}{c}{ Naskah LKS yang ditelaah } & \multicolumn{1}{c}{ Topik } \\
\hline 1 & $\begin{array}{l}\text { LKS Kharisma. Pengarang: Lestari PJ. } \\
\text { Penerbit: CV Haka MJ }\end{array}$ & Pengukuran \\
\hline 2 & LKS yang dibuat oleh sekolah sendiri & Sistem Gerak \\
\hline 3 & $\begin{array}{l}\text { LKS Kimia Untuk SMA Kelas II A Peminatan } \\
\text { MIA. Penerbit: Kharisma }\end{array}$ & Reaksi Eksoterm-Endoterm \\
\hline 4 & $\begin{array}{l}\text { PR Ilmu Pengetahuan Alam SMP Kelas VIII. } \\
\text { Penerbit: Intan Pariwara }\end{array}$ & $\begin{array}{l}\text { Sistem Pencernaan pada } \\
\text { Manusia }\end{array}$ \\
\hline 5 & $\begin{array}{l}\text { LKS Kelas 4. Penyusun: Forum } \\
\text { Peningkatan Profesi Guru. Penerbit: } \\
\text { Lentera Ilmu }\end{array}$ & Selalu Berhemat Energi \\
\hline 6 & LKS Kelas 2 SD. Penerbit: Sinar Mandiri & Bermain di Lingkungan \\
\hline 7 & LKS Kelas 2 SD. Penerbit: Intan Pariwara & Gemar Berolahraga \\
\hline
\end{tabular}

Tabel 2. Rekapitulasi Hasil Telaah LKS oleh Tiap Kelompok

\begin{tabular}{crrrrrrr}
\hline \multirow{2}{*}{ Komponen telaah } & \multicolumn{7}{c}{ Persentase skor hasil telaah } \\
\cline { 2 - 8 } & kel 1 & kel 2 & kel 3 & kel 4 & kel 5 & kel 6 & \multicolumn{1}{c}{ kel 7 } \\
\hline Identitas LKS & 80.95 & 90.48 & 90.48 & 100 & 90.48 & 90.48 & 100 \\
\hline Syarat teknis & 95.24 & 90.48 & 100 & 95.24 & 95.24 & 95.24 & 85.71 \\
\hline Syarat konstruksi & 95.24 & 100 & 100 & 95.24 & 100 & 100 & 100 \\
\hline Isi & 95.24 & 90.48 & 100 & 100 & 100 & 100 & 95.24 \\
\hline Melatihkan sikap ilmiah & 80.95 & 95.24 & 100 & 95.24 & 100 & 95.24 & 90.48 \\
\hline
\end{tabular}

Hasil telaah peserta menunjukkan bahwa LKS yang biasa digunakan di sekolah masih memiliki kekurangan baik dari segi identitas LKS, syarat teknis, syarat konstruksi, isi, maupun melatihkan sikap ilmiah. Persentase ketidaksesuaian yang paling besar terdapat pada komponen identitas LKS dan syarat teknis. 
Ditinjau dari komponen identitas LKS, hasil telaah oleh peserta kegiatan PKM menunjukkan bahwa 57,14\% LKS yang biasa digunakan di sekolah belum mencantumkan tujuan pembelajaran dan $42,86 \%$ belum mencantumkan alokasi waktu dan daftar pustaka. Padahal ketiga hal tersebut sangat diperlukan dalam suatu bahan ajar.

Tujuan pembelajaran diperlukan dalam LKS (Widjajanti, 2008). Tujuan pembelajaran dalam LKS diperlukan oleh guru untuk melihat cakupan materi yang disediakan oleh LKS tersebut. Dari tujuan inilah kemudian guru seharusnya mencocokkan dengan tujuan yang telah ditetapkan dalam rencana pembelajaran. LKS yang tidak mencantumkan tujuan pembelajaran dapat memperbesar kemungkinan ketidaksesuaian antara tujuan pembelajaran dan tujuan LKS yang akhirnya berujung pada ketidaktercapaian tujuan pembelajaran.

Alokasi waktu dalam LKS diperlukan oleh guru maupun siswa. Alokasi waktu LKS dapat membantu guru menempatkan LKS dalam langkah pembelajaran yang akan diterapkan. Alokasi waktu LKS dapat memacu siswa untuk penyelesaian tugas tepat waktu. Dengan kata lain, alokasi waktu dapat memacu tanggung jawab siswa untuk penyelesaian tugas.

Daftar pustaka sangat bermanfaat bagi guru. Selain dapat digunakan untuk membantu penentuan nilai kebenaran konsep yang disajikan dalam LKS, daftar pustaka juga dapat digunakan untuk penelusuran lanjut. Penelusuran lanjut ini menjadi sangat penting ketika konsep yang disajikan merupakan konsep baru atau konsep yang belum dikenal oleh guru. Daftar pustaka dapat digunakan oleh guru untuk memastikan bahwa LKS tersebut tidak mengacu pada buku sumber yang diluar kemampuan keterbacaan peserta didik, sesuai dengan pendapat Widjajanti (2008).

Ditinjau dari syarat teknis, hasil telaah peserta PKM menunjukkan bahwa LKS yang biasa digunakan di sekolah $85,71 \%$ belum menyajikan gambar dan warna yang menarik. Hal ini perlu diperhatikan sebab penampilan LKS yang menarik dapat meningkatkan daya tarik LKS tersebut sedemikian hingga dapat meningkatkan motivasi belajarnya (Widjajanti, 2008).

Ditinjau dari komponen melatihkan sikap ilmiah, hasil telaah peserta PKM menunjukkan bahwa sebagian LKS yang biasa digunakan di sekolah belum menyajikan kemampuan menanya, mengamati, mengumpulkan data, mengasosiasikan dan mengomunikasikan. Padahal kelima hal tersebut merupakan pendekatan saintifik yang berupakan dasar dari pengembangan kurikulum 2013. Sikap ilmiah yang presentasenya paling banyak dijumpai adalah komponen menanya, yaitu sebesar 42,86\%. Menanya merupakan langkah yang sangat penting dalam pembelajaran kurikulum 2013. Dengan menanya, siswa diharapkan mampu mengorganisir dirinya untuk mau bertanya tentang pembelajaran yang akan dilaluinya. Hal ini kemudian akan membangkitkan rasa ingin tahunya. Rasa ingin tahu inilah yang akan menjadi motivasinya selama mengikuti 
pembelajaran sampai tercapainya tujuan pembelajaran.

\section{c. Penentuan Topik LKS}

Kelompok kerja menentukan topik LKS sesuai dengan Kompetensi Dasar yang tercantum dalam Kurikulum 2013. Tim PKM mendampingi kelompok kerja dengan mengarahkan mereka pada bentuk kegiatan praktikum (hands on) berbasis pendekatan saintifik serta konsep apa saja yang dikuasai siswa setelah mengerjakan kegiatan LKS.

\section{d. Penyusunan Desain LKS}

Kelompok kerja melanjutkan kegiatan dengan menyusun desain LKS. Tim PKM memberikan masukan berupa saran dan mengingatkan kembali tentang syarat LKS yang baik. Desain LKS yang disusun meliputi komponen-komponen LKS antara lain topik kegiatan, identitas siswa, alokasi waktu, tujuan kegiatan, alat dan bahan, dan kegiatan yang berorientasi $5 \mathrm{M}$.

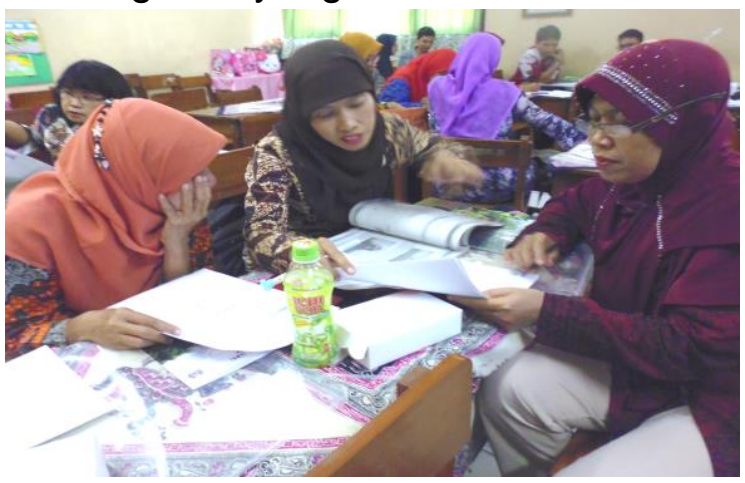

Gambar 1. Kelompok kerja mendiskusikan desain LKS yang akan disusun

Setelah melakukan telaah terhadap LKS yang biasa digunakan di sekolah, peserta PKM diminta untuk membuat design atau mengembangkan LKS berbasis pendekatan saintifik. Dengan melakukan telaah, peserta
PKM diasumsikan telah menemukan kekurangan dari LKS yang biasa digunakan untuk kemudian mengembangkan LKS yang baik berbasis pendekatan saintifik dengan cara memperbaiki kekurangan yang telah ditemukan.

Tahap pengembangan LKS dilakukan saat kegiatan PKM dan dilanjutkan dengan tugas mandiri. Pada tahap pengembangan awal LKS, peserta PKM diminta untuk menentukan design awal LKS yang akan dikembangkan yang meliputi judul, tujuan, konsep dan gambaran singkat tentang isi LKS yang akan dibuat. Desain awal inilah yang kemudian dikonsultasikan pada tim PKM. Pada kegiatan konsultasi ini, tim PKM melakukan pengecekan dan koreksi jika ada yang salah terutama konsep ataupun penerapan kegiatan $5 \mathrm{M}$.

Pada kegiatan konsultasi, terdapat temuan-temuan menarik terkait dengan pemahaman yang dimiliki oleh peserta PKM, sebagai berikut:

1) Dalam hal penentuan judul, peserta PKM tidak memiliki kesulitan. Semua judul yang dibuat pada desain awal sudah menarik dan sesuai dengan konsep yang akan diajarkan.

2) Dalam hal penentuan tujuan terdapat temuan menarik antara lain:

a) Peserta menganggap bahwa semua tujuan yang ada di rencana pembelajaran (RPP) harus ada dalam LKS sehingga tujuan yang dituliskan sangat banyak dan 
tidak semuanya tercakup dalam kegiatan LKS tersebut.

b) Peserta PKM ternyata belum dapat mengetahui batasan definisi tujuan belajar dan konsep. Konsep yang dituliskan sangat mirip dengan judul, sedangkan tujuan pembelajaran dituliskan sama seperti konsep dengan ditambahkan kata-kata siswa dapat di awal kalimatnya.

c) Tujuan yang telah ditetapkan oleh sebagian peserta belum mengandung unsur audience, behaviour, condition dan degree $(A B C D)$.

3) Peserta menganggap LKS dapat digunakan sebagai alat evaluasi belajar sehingga isinya berupa soal-soal yang kemudian dinilai sebagai hasil belajar.

4) Beberapa peserta tidak bersemangat membuat LKS karena merasa bahwa membuat LKS itu merupakan hal yang sulit dan memerlukan banyak waktu.

5) Terdapat beberapa kelompok yang belum dapat mensinergikan tujuan dan konsep sehingga tujuan dan konsep yang ditetapkan menjadi kurang sesuai satu sama lain.

e. Penutup Pelatihan

Kegiatan pelatihan diakhiri dengan penyusunan agenda penyelesaian LKS bersama tim PKM. Kesepakatan bersama naskah LKS yang sudah disusun dikirimkan melalui email salah satu anggota tim PKM yaitu evakrisnawati@gmail.com._Kegiatan diakhiri dengan pengisian angket respons guru terhadap pelaksanaan pelatihan Penyusunan LKS berbasis Kurikulum 2013.

\section{Respons Guru Terhadap Pelaksanaan Kegiatan}

Angket yang telah diisi dikembalikan ke tim PKM. Sebanyak enam belas angket yang diterima tim PKM. Ini berarti ada peserta yang tidak mengisi. Selama kegiatan PKM memang ada 4 guru SMP yang hadir tetapi di tengah kegiatan berlangsung keluar minta ijin melakukan tugas sekolah. Berdasarkan hasil rekapitulasi angket respons disajikan dalam tabel berikut ini:

Tabel 3. Rekapitulasi Respons Peserta Terhadap Pelaksanaan PKM

\begin{tabular}{cllc}
\hline \multirow{2}{*}{ No. } & \multicolumn{1}{c}{ Uraian Pertanyaan } & \multicolumn{2}{c}{ Persentase } \\
\cline { 3 - 4 } & \multicolumn{1}{c}{ Ya } & Tidak \\
\hline 1. & $\begin{array}{l}\text { Apakah menurut Bapak/lbu/Saudara materi pelatihan ini } \\
\text { merupakan hal yang baru? }\end{array}$ & 70 & 30 \\
\hline 2. & $\begin{array}{l}\text { Jika materi ini merupakan hal yang baru, apakah materi ini } \\
\text { menarik? }\end{array}$ & 100 & 0 \\
\hline 3. & $\begin{array}{l}\text { Jika materi ini merupakan hal yang baru, apakah } \\
\text { Bapak/lbu/Saudara tertarik mengikutinya? }\end{array}$ & 100 & 0 \\
\hline 4. & Apakah menurut Bapak/lbu/Saudara tertarik mengikutinya? & 100 & 0 \\
\hline
\end{tabular}




\begin{tabular}{clcc}
\hline 5. & $\begin{array}{l}\text { Apakah menurut Bapak/lbu/Saudara pelatihan ini bermanfaat } \\
\text { bagi profesi Anda? }\end{array}$ & 100 & 0 \\
\hline 6. & $\begin{array}{l}\text { Apakah Tim PKM mempersiapkan pelaksanaan pelatihan } \\
\text { dengan baik? }\end{array}$ & 100 & 0 \\
\hline 7. & $\begin{array}{l}\text { Apakah Tim PKM menguasai dengan baik materi yang } \\
\text { disampaikan? }\end{array}$ & 100 & 0 \\
\hline 8. & Jika tidak, dalam hal apa? & 100 & 0 \\
\hline 9. & $\begin{array}{l}\text { Apakah Bapak/lbu/Saudara mudah memahami materi yang } \\
\text { disampaikan Tim PKM? }\end{array}$ & 100 & 0 \\
\hline 10. & $\begin{array}{l}\text { Apakah menurut Bapak/lbu/Saudara prinsip-prinsip dari materi } \\
\text { ini mudah untuk direalisasikan di sekolah? }\end{array}$ & 90 & 10 \\
\hline 11. & Apakah kegiatan PKM ini terlaksana dengan baik? & 100 & 0 \\
\hline 12. & $\begin{array}{l}\text { Materi apa yang Bapak/lbu/Saudara butuhkan untuk } \\
\text { selanjutnya? }\end{array}$ & 100 & 0 \\
\hline & $\quad$ Rata-rata & $\mathbf{9 6 , 6 7}$ & $\mathbf{3 , 3 3}$ \\
\hline
\end{tabular}

Sejumlah 30\% dari peserta PKM menyatakan bahwa kegiatan PKM bukan merupakan hal yang baru. Meskipun demikian, sebagian peserta menyebutkan bahwa mereka sudah pernah menjalani workshop tentang Kurikulum 2013 tetapi belum dikaitkan dengan pengembangan LKS berbasis saintifik. Sebagian peserta juga menyatakan bahwa sudah menjalani kegiatan serupa tapi tidak sejelas dan sebaik kegiatan PKM yang baru saja dilaluinya.

Sejumlah $10 \%$ dari peserta PKM menyatakan bahwa prinsip dari materi PKM sulit direalisasikan di sekolah. Sebagai alasannya, peserta menyebutkan bahwa mengembangkan LKS sendiri memerlukan waktu dan tenaga dimana mereka seharusnya dapat melaksanakan tugas lain seperti tugas-tugas administrasi. $\mathrm{Hal}$ ini menunjukkan bahwa terdapat peserta PKM yang kurang memiliki kesadaran untuk selalu mengembangkan kompetensi yang dimilikinya serta berupaya untuk melaksanakan pembelajaran yang baik bagi siswanya.

Jika ditinjau secara keseluruhan, rata-rata respons positif terhadap pelaksanaan workshop Penyusunan LKS berbasis Kurikulum 2013 sebesar $96.67 \%$. Ini berarti bahwa kegiatan PKM oleh tim dosen jurusan Biologi, Unesa telah terlaksana dengan baik karena memenuhi kriteria $80 \%$ peserta memberikan respons positif (menjawab ya) untuk 12 pernyataan yang terkait aspek materi pelatihan, manfaat pelatihan, kompetensi tim PKM dan keterlaksanaan PKM.

\section{LKS yang Dihasilkan Guru Peserta Workshop}

Lembar Kegiatan Siswa yang telah dihasilkan oleh guru dikirimkan pada Tim PKM melalui alamat email seperti yang telah disepakati bersama. Namun, ternyata guru tidak mengumpulkan hasil LKS tepat waktu. Tim PKM kemudian mengingatkan peserta mengenai komitmen yang telah disepakati bersama. Hal ini merupakan 
salah satu kendala yang dihadapi Tim PKM, yaitu guru-guru menjadikan tugas administrasi sekolah sebagai alasan untuk mengulur batas waktu pembuatan LKS.

Terdapat tujuh LKS yang dihasilkan oleh peserta, sesuai dengan jumlah kelompok yang telah dibentuk. Hasil review LKS yang dihasilkan guru oleh Tim PKM menunjukkan bahwa masih ada beberapa hal yang harus diperbaiki oleh guru dalam penyusunan LKS, antara lain belum adanya alokasi waktu dan tujuan pembelajaran dalam LKS serta minimnya penggunaan gambar dan warna untuk meningkatkan motivasi belajar siswa. Selain itu, terdapat miskonsepsi dalam melatihkan sikap ilmiah, khususnya dalam hal menanya. Dalam beberapa LKS yang dihasilkan oleh guru, kegiatan melatihkan keterampilan menanya dilakukan dengan menyajikan sebuah pertanyaan yang selanjutnya akan menjadi tugas siswa untuk menjawab pertanyaan tersebut. Hal ini akan menjadi lebih baik jika disajikan fenomena atau uraian yang membangkitkan rasa ingin tahu siswa sehingga mereka dapat mengajukan sendiri pertanyaan yang akan menjadi tugas belajarnya.

Hasil review terhadap LKS yang dikembangkan oleh guru kemudian dikembalikan pada peserta untuk kemudian diperbaiki dan dikirimkan kembali kepada Tim PKM untuk divalidasi. Hasil validasi menunjukkan bahwa produk akhir LKS yang dikembangkan guru masih terdapat beberapa hal dalam LKS yang belum diperbaiki sesuai hasil review Tim PKM, antara lain belum adanya alokasi waktu dan tujuan pembelajaran pada LKS serta minimnya penggunaan gambar dan warna untuk meningkatkan motivasi belajar siswa.

\section{SIMPULAN DAN SARAN}

Berdasarkan uraian hasil dan pembahasan dapat disimpulkan sebagai berikut:

1. Pelatihan penyusunan LKS berbasis Kurikulum 2013 bagi guru-guru Yayasan Kemala Bhayangkari Surabaya dapat terlaksana dengan baik.

2. Lembar Kegiatan Siswa berbasis Kurikulum 2013 yang dihasilkan oleh guru-guru Yayasan Kemala Bhayangkari Surabaya telah memenuhi syarat LKS yang baik ditinjau dari identitas LKS, syarat teknis, kebahasaan, isi/konsep dan sikap ilmiah yang dilatihkan.

3. Guru peserta pelatihan memberikan respons yang baik terhadap pelaksanaan pelatihan penyusunan LKS berbasis Kurikulum 2013 di sekolah Kemala Bhayangkari Surabaya.

Agar kegiatan PKM semacam ini yang dilaksanakan di sekolah dapat berjalan lancar, maka saran yang dapat diajukan sebagai berikut:

1. Waktu pelaksanaan PKM sebaiknya dipilih tidak pada saat kegiatan efektif belajar mengajar.

2. Agar kualitas produk yang dihasilkan oleh guru setelah mengikuti kegiatan PKM optimal hendaknya kunjungan tim PKM ke sekolah lebih dari satu kali. Komunikasi tentang produk 
melalui email tidak efektif, karena tim PKM tidak langsung bertatap muka dengan peserta workshop untuk membahas produk sampai menghasilkan produk yang diharapkan.

\section{DAFTAR PUSTAKA}

Departemen Pendidikan Nasional. 2004. Pedoman Umum Pengembangan Bahan Ajar Sekolah Menengah Atas. Jakarta: Direktorat Pendidikan Menengah Umum.

Fitrihidajati, Herlina, dkk. 2009. Laporan Penelitian Hibah Pekerti Tahun Pertama Penerapan Berbagai Tipe Pembelajaran Kooperatif pada Pembelajaran Biologi untuk Meningkatkan Kemampuan Berpikir Kritis dan Hasil Belajar Siswa. Surabaya: LPPM Unesa.

Fitrihidajati, Herlina, dkk. 2010. Laporan Penelitian Hibah Pekerti Tahun Kedua: Penerapan Berbagai Tipe Pembelajaran Kooperatif pada Pembelajaran Biologi untuk Meningkatkan Kemampuan Berpikir Kritis dan Hasil Belajar Siswa. Surabaya: LPPM Unesa.
Fitrihidajati, Herlina. 2013. Laporan Pendampingan Implementasi Kurikulum Bagi Guru IPA di Bangkalan. Jakarta: Kerjasama Direktorat PSMP.

Kementerian Pendidikan dan Kebudayaan. 2012. Dokumen Kurikulum 2013. Jakarta: Direktorat Pendidikan Tinggi.

Nuh, Mohammad. 2013. Peraturan Menteri Pendidikan dan Kebudayaan Nomor 69 Tahun 2013 tentang Kerangka Dasar dan Struktur Kurikulum Sekolah Menengah Atas/ Madrasah Aliyah.

Widjajanti, E. 2008. Kualitas Lembar Kerja Siswa (LKS). (Makalah disajikan dalam Seminar Pengabdian pada Masyarakat. Pelatihan Penyusunan LKS Mata Pelajaran Kimia Berdasarkan KTSP bagi Guru SMK/MAK pada 22 Agustus 2008.) Yogyakarta: Universitas Negeri Yogyakarta. 